Metodički obzori 7(2012)2

Original research paper

UDK: $37(945=163.6)$

Received: 27. 1. 2011.

\title{
CONTEMPORARY EDUCATIONAL PROCESSES IN THE SLOVENE RELIGIOUS CENTRE OF STS. CYRIL AND METHODIUS IN AUSTRALIA IN THE PRESERVATION OF SLOVENE EMIGRANTS
}

\author{
Prof. Jana Goriup, PhD \\ Faculty of Arts, \\ University of Maribor (Slovenia) \\ e-mail: jana.goriup@uni-mb.si
}

\begin{abstract}
A b stract
Intense emigration of Slovenes to Australia, especially to Victoria State, commenced after WW I and reached its climax in the 1970s. The Slovenians in Australia are the fourth largest non-European immigrant community and they felt the need to organize their cultural and social life a long time ago. The article discusses one of the major and first organizations of the Slovene emigration: The Religious Centre of Sts. Cyril and Methodius in Kew, Melbourne, which has for decades been providing shelter for many of the emigrants and their families. The article especially considers the educational role of the Franciscan priests. As they built a wide network of their educational activities soon after their arrival in 1955, the Centre surpassed the boundaries of a Catholic Franciscan "Mission". Two of the most exposed goals of their religious, social and educational roles have been the preservation of the Slovene heritage and education aiming at integration of Slovene emigrants in Australian everyday's life. Through activities of the Centre, the Slovene emigrant community managed to form an immanent and specific way in transmitting the ethnic particularities of the native country both to their younger generations and to the Australian social environment (through the monthly review "Misli", Slovenian school, language classes, choirs, sporting and social activities, radio etc.).

Finally, as the paper is a result of a case study research including direct involvement in the research, the author tries to answer the question whether the above mentioned educational activities have lead to an establishment of a more positive relationship between the majority (Australians) and minority (Australian Slovenes) communities.
\end{abstract}

Key words: identity management, emigration, citizenship, education, Slovene emigrant community, Franciscan priest 


\section{Introduction}

Social mobility of the Slovenian population, which is also a special form and part of international migration, a phenomenon which was intensively present during the boom in the $20^{\text {th }}$ century, got its inherent specificity and became a fixture of the Slovenian nation especially after WW II. As such, migration is understood as a specific social and economic process and a category which, due to its specific flows, processes, forms and functions, is separated from the processes of colonization. When we talk about migration of Slovenians to Australia, based on empirical data obtained directly from the field, we note that in history the migration processes of the Slovenians to Australia took place due to different causes:

- political (as renegades, dissidents, asylum seekers, disagreeing with the political, ideological and cultural and economic conditions and/or changes, and others), which were the most common;

- economic (job search, new sources of income, career paths, etc.)

- philosophical (membership of a particular religion, political party or movement, search for "peace", etc.), and

- personal (marriage), etc.

Although migration has been a constant in the Slovenian social mobility since the mid- $19^{\text {th }}$ century, the period between the Two World Wars registered very few Slovenian migrants and it is generally accepted that there was no organised Slovenian community in Australia in existence at that time. The first significant wave of Slovenian migrants arrived in Australia during the period 1946 to 1951. Many refer to this wave of migrants as immigrants due to their political displacement after World War II. Some were in conflict with the new regime in Yugoslavia, and many were "displaced persons" on ideological grounds. The second, and by far the greatest wave of migrants from Slovenia, arrived between the years 1951-1960. This migration was predominantly economically motivated due to the economic reality of the poor post-war Slovenia within the Yugoslavian federal state. Nevertheless, there were still a significant number of migrants in this period who were motivated by their opposition to the existing socialist regime in Yugoslavia. In the 1960s the strong wave of immigration was falling rather sharply, with very few Slovenian migrants registered after 1975 (Fr. Valerijan Jenko, 12.3.2010.).

However, labour migration into and within Australia slowed down until the beginning of the present century. Various economic problems in Slovenia, inflexible unemployment, poverty and rising social inequality reversed the situation in the present century.

Many times the decision of an individual and/or of social groups to emigrate to Australia helped generate more and different social factors. Although modern migration of Slovenes to Australia or its federal states are usually referred to as temporary, this does not also mean that the Slovenian migrants do not become permanent migrants. Slovenian temporary migrants in Australia differ from the 
permanent ones. While living in Australian society, where they took part in several complex processes of social interaction in a new social and cultural environment, they still maintained contact with their social environment or native society to which they were planning to return. Also, the modern information technology allowed them better communication than it was possible to their predecessors.

Temporary migrants in the Australian immigrant society are involved in the processes of accommodation, the initial stage of adaptation, and acculturation; depending on the intended period of staying and (especially) the cause of the arrival in Australian society. However, we note that working processes are highly associated with problems of adaptation, and (often) with inadequate organization (Alfred Brežnik, Honorary Consul of the Republic of Slovenia, Sydney, 17/03/2010).

In general, the (various) migration processes commenced due to the precarious situation in the labour market in the native Slovenian society, and saw a mass participation of the workforce looking for new sources of income and professional career, but also a sense of security and freedom.

The conducted sociological and historical researches (Birsa, 1994; Čebulj Sajko, 2001; Koderman, 2007, etc.) dealing with migration issues of Slovenian life and the life and work of people in the (global) Australian society, treated also the issues of historical and sociological causes of departure from the Slovenian society and were focused on the economic problems of the Slovenian migrants in the new, immigrant (Australian) society. Insufficient attention was paid to the problem of adaptation to the new environment, (in)voluntary adoption of new, often enforced cultural, moral and other values and problems that were experienced by the migrant population. Either because of changes in the value system and problems in accustoming to a new social environment, or because of aggressive assimilation processes upon parents and their offspring, their wishes to maintain their native and national identity were obstructed.

\section{Some characteristics of Slovenian permanent emigrants in Australia}

Permanent emigrants from Slovenia have settled in Australia in (almost) all its states and territories. The majority of them live in Victoria, New South Wales and Queensland, but can also be found in other states (Tasmania, South Australia, and Western Australia). Intensive economic migration processes took them from the underdeveloped domestic agricultural areas into the Australian environment, to industrial and urbanized centres as well as to less developed rural areas.

They, and generations of their offspring born abroad, are considered to be the most permanent emigrants and have undergone an intensive assimilation processes. However, and especially where the Slovenians live in compact communities, the immigrant communities have always tried to maintain their native culture, to resist the (unnecessary) assimilation, and to maintain ties with their homeland. They are permanently seeking for connections with the immigrant Australian society. 
The Australian community has provided permanent emigrant accommodation and facilitated the processes of adaptation. It is true that Australia pays attention to its (mostly economic) emigrants in providing them with the associated rights, assisting them in their cultural and recreational activities, enabling the organization of supplementary education, providing them with information for a fast and efficient socialization into new society; but it is also true that with the stricter statutory standards for obtaining permanent residence, including the right to citizenship, it is trying to optimize their integration into the global Australian society.

However, it is not possible to ignore many conflicts, and discrimination and segregation problems, which have accompanied permanent migrants because of their minority status, resulting from the phenomena of ethnic stratification in Australian (global) society.

\section{The role of the religious Slovenian Centre of Sts. Cyril and Methodius in Kew, Melbourne}

The first generation of Slovenian immigrants, who arrived in Australia immediately after World War II, were accommodated in organised reception centres (e.g. Bonegillia, Maitland, Sydney, Bunnerong, Cabra etc.), where they stayed in barracks that were poorly equipped, because “... circumstances in the camps were severe: in the rooms there were no tables, no chairs, only a space barely enough to place one double and one single bed (....) Accommodation was intolerable; especially the metal shacks that were without ceiling insulation. They were extremely hot during the day and very cold at night" (Father Claudius, 07.06.1951).

Consequently, people were forced to spend their modest savings on deposits for purchase of (mostly old) houses to alleviate daily problems and to allow the previously separate families to live together. Special government agencies helped them to find jobs and better housing. The migrants had to sign a special two-year contract under which the federal government authorities not only limited the scope of employment (in subtropical climate chopping sugar cane, building roads, open mining of bauxite, iron ore, etc.), but also place and stay. In this way emigrants were committed to obey the "Certificate of Registration", by Department of Immigration.

\section{Powerful sense of isolation caused different activities}

Most Slovenians settled in the state of Victoria, living far apart, but still felt the need to socialize and help each other. The Slovenian Roman Catholic Church was well aware of this fact and has actively coped with the problem of Slovenian emigrant population since the early 1950s. Already in 1951 Bishop Rožman sent two Slovenian Franciscan priests from the USA to Sydney, NSW, not only to serve the Slovenian Community for religious, but also for social and cultural purposes. Fathers Beno Korbič and Klavdij Okorn began the long tradition of Franciscan service in Australia. When they returned to the USA in 1953, Father Rudolf and the diocesan priest Mikula continued their work. A steady stream of Slovenian priests 
continued to come to Australia, first from the USA and then from Slovenia. In 1966 the Slovenian priests were joined by nuns of the Order of the Immaculate Conception and were very active until 1991. The work done both by priests and the nuns has varied, changing according to the nature of the (local) Slovenian Community and of themselves (Gelt, Ferfolja, 2001).

The Slovenian immigrants were overwhelmed by a powerful sense of isolation from their new and foreign environment; an additional obstacle to the gradual assimilation and socialization with the environment was also the lack of knowledge of the English language, which in turn led to even more intensive interconnections of the Slovenes (Birsa, 1994, 139). The arrival of the Franciscan priests was consequently of an even greater importance, not only regarding the spiritual care, but also because of incentives and assistance in organizing societies and the first magazines in the Slovenian language: Thoughts (issued monthly since 1952), Slovenian Chronicle (1954), Vestnik (1955) and others.

Eventually, the economic situation of the Slovenes improved. Because of their conscientious and quality work and a modest lifestyle, in the 1960s they started selling their old houses in less prestigious areas, and moving to new houses, either from rural areas to larger urban centres or to more prestigious neighbourhoods. This also gave them the opportunity to associate with their fellow countrymen more often, to exercise their religious and cultural needs and gather together. "Slovenians always liked to get together socially. In their new homeland this was more important than ever, because of difficulties with the new language, customs, culture and many other factors." (Valerijan Jenko, 8.2. 2010.) Father Klavdij Okorn (1912-1979) of the Catholic Migration Office obtained the permit in 1952 to celebrate the Sunday mass in the Slovenian language in the church of St. Carthage (Okorn, 1952.7). In 1956, following the arrival of Father Bernard Ambrožič (1892-1973), regular worship began in Melbourne, but it was suspended when Father Pivko fell ill.

\section{Bazilij Valentin's significant role in social and religious life of Australian Slovenes in Victoria}

The decisive change in social and confessional life occurred with the arrival of Bazilij Valentin (1924-1997) to Padua Hall in Melbourne in September 1956. He established Slovenian religious centres, starting with the Slovenian mass in Burnelyu, followed by the Slovenian religious centre of Sts. Cyril and Methodius, whose primary goal has always been to facilitate religious activity, which was extended to the cultural, social and cultural area. With its pastoral, educational, cultural and economic performance, which lasted 41 years, he greatly marked the social and religious life of Australian Slovenes, not only in Victoria but all across the fifth continent.

First, he organized the activities of the Baraga home for (mostly male) Slovene immigrants, then he organised voluntary contributions and work of the Slovenians in the building of churches and cultural facilities and in 1992 the home 
for the elderly Slovenian compatriots and the purchase of plots for Slovenian common graves in the cemetery of Keilor.

In 1960 the archdiocese of Melbourne granted permission to celebrate masses and other ceremonies during the holidays in the chapel of the St. Anthony Padua Hall, which was renamed the Chapel of St. Mary Help of Christians. One year later, the midnight mass and the celebration of Easter and the Assumption were held (Valentin, 1961, 356). In 1963 the "Lourdes Cave" was built in the courtyard of Baraga home (similar to "American Brezje" in Lemont, USA). In it they started with the implementation of formal worship, prayers and certain rituals (e.g. baptism), they made a Nativity scene, Easter tomb, various processions, for which the facility is still used today. Bilingual celebrations and ceremonies are developed under the (still present) tradition of the Slovenian community, attended by more than 1,000 Slovenians and their descendants, who are actively involved in them.

In the Croatian Church of the Blessed Nikola Tavelić in Clifton Hill, Valentin organized from 1963 the daily worship in the Slovenian language, because the new Church of Sts. Cyril and Methodius was only consecrated in 1968. Already at that time he organized worship throughout the State of Victoria, from St. Albans, Geelong, Morwell, Seymore, Albury-Wodong to Ballarat, and in the suburbs of Springvale, Noble Park, Altona North and elsewhere. With all these activities he decisively contributed to the preservation of the national identity of Slovenian immigrants. For 25 years he was editor of the monthly magazine of religious thought, which is still issued today, and the British journal The Baraga Bulletin (Gelt and Ferfolja, 2001.70). That his role was more than just religious in nature is shown by a number of awards and prizes the Father won for his active social work, in particular his educational, cultural and political (after the independence of Slovenia) work: Queen Elizabeth II awarded him with the title Member of the Most Excellent Order of the British Empire (Valentin, 1982.172), he received the Honorary Sign of Freedom of the Republic of Slovenia in 2000 (posthumously) and the highest decoration of the Slovenian World Congress (Gelt and Ferfolja, 2001,109).

With the help of Slovenian immigrants, a building, a former correctional home, was remodelled into a hostel for the needs of Slovenian immigrants. These were the Slovenes who were not informed of and introduced to the new society, often due to ignorance of the language, and were subjected to exploitation by various marginalized groups that hurt them as soon as they arrived in the port of Melbourne. The new centre began its work in 1960. A special place for social gatherings and sports activities was also created; for the purposes of the cultural life of Slovenes a library was established. A centre was also established to provide for health and social needs of the Slovenians followed by the Welfare \& Information Office to assist them in obtaining welfare and information and to provide administrative services.

The immigrants could stay in the hostel until they found a suitable employment and a place of residence. Fathers Valentin and his successors helped 
selflessly. In agreement with the diocese, the buildings were renamed the Baraga House in 1963 (Ivan Lapuh, 22.3.2010).

Today the centre still fulfils its original mission; the residence also offers accommodation to a number of Slovenians visiting the fifth continent.

In 1963, at the initiative of father Bazilij Valentin, Branko Tavčar, B.Sc. and artist Vladimir Rosič elaborated a plan for the construction of the Slovenian Church within the Baraga's House area, which was approved by the Kew town's municipality a half year later. The building also included (in the basement) a multipurpose hall for the gathering of Slovenes. The idea and the plans received much acclaim by the local Slovenes who established a dedicated fund called the "Baraga House Memorial Fund" to collect the necessary funds and who carried out most of the works voluntarily. The church was completed and consecrated in July 1968 and soon became a stable place of worship in the Slovenian language.

Nevertheless, we must emphasise, that the Slovenian Franciscan Fathers have always allowed Catholics of other ethnic groups (e.g. Tonga, Slovaks, etc.) to organise their religious activities in the church. The Hall provides the desired companionship of fellow countrymen, allows performances of cultural groups, associations, various concerts, shows, events, etc. This was especially important at the beginning, before other Slovenian associations and clubs in Victoria built their homes.

Eventually, the first generation of Slovenian immigrants, who were the leaders of the development of organized social life of the Slovenian community, has changed. Their children were initially more, but later becoming less intensively involved in the life of the Slovenian community. Having obtained jobs, often very distant from the place of residence, they felt the problem in sustaining their weakened, ill and elderly parents. The initiative of Father Bazilij, who obtained from the Melbourne diocese a nearby building, Carnsworth, a former Presbyterian home for the elderly, was more than welcome. The home was later renamed to "Slomšek's Home".

\section{Slovenian Sisters of the Immaculate Conception helping Australian Slovenes in Victoria}

When the work with the elderly was initiated in 1966, after the Slomšek's Home acquired a license and registration of the State Department of Health, some Slovenian nuns felt attracted to this kind of work. The first nuns arrived on April $4^{\text {th }}$ 1966. The possibility for the elderly and often ill members of the community to stay in nearly authentic and known system of values that prevailed in their native environment relieved the generation of their relatives and enabled the elderly to round off their lives peacefully and in a familiar surrounding.

The nuns worked with the elderly in the home, visited patients in their homes and took over the Slovenian kindergarten "Slomšek Child Minding Centre" and the Slovenian school. In accordance with the law, the sisters could care for and supply up to eight children, two to three and three to five years old, regardless of their 
nationality. They provided hospitality to the priests, the Hostel residents, and to many guests. They provided support to the Slovenian community and did a lot of sewing of costumes for performances, national costumes, Christening clothes and cloths for the Altar, they organized the Church Choir, led the folklore group Rosemary etc. (Gelt, Ferfolja, 2001, 350).

The mission of the nuns ended in 1992, partly because of their own personnel problems, partly due to declining interest by the Slovenian parents for such activities. The Slomšek's Home building was returned to the Melbourne diocese.

But the need to work with older people remained, as the migrant population inevitably grew old and their descendants lived in the grip of the daily requirements of the Australian post-modern reality. Father Bazilij was restless and after long (even legal) complications succeeded in obtaining the consent and authorization to open the "Mother Romana Home", which was opened in the presence of local ecclesiastical and civil political authorities on June $2^{\text {nd }} 1992$.

In the mid 1970s, the religious centre of the Slovenian Society organized the St. Ema's society, first led by the order of the Franciscan Sisters of the Immaculate Conception. Their activities included the activities with which they wanted to maintain the Slovenes, members of other ethnic entities, preserve the present values of the native society, characteristics of Slovenian cuisine, Slovenian customs and habits. In particular, members of this League are still preparing snacks for various events, celebrations and the family dinner (once a month) (Silva Bogovič, 19/03/2010).

They always played an active role in the functioning of the Slomšek's School, established in 1960 with the purpose of teaching the (Slovene) mother tongue, the transmission of the contents of Slovenian culture and preparation of exhibitions on ethnographic themes, the annual mother's and father's day celebrations etc.

The lessons in Slovene were initially held once a month (after Sunday Mass) and from 1961 onwards twice a month. The educational school work was at a high level and of high quality, and the work was recognized by the decision of the Ministry of Education, State of Victoria, who in 1976 introduced the opportunity to study Slovenian language as a school subject in secondary schools, which could be elected by a prescribed number of students instead of a second foreign language. (Lucija Srnec, 22.3. 2010).

Valentin $(1976,245)$ stated that in the following school year was already implemented with Slovenian language teaching in secondary schools in Melbourne, Maribyrnong and in Box Hill. The great satisfaction of students and their parents in the 1990s enabled the justified introduction of the Slovenian language as an elective secondary school course across the state. From the statistics it is clear that this option required enrolment of at least 10 students per generation. However, it is gratifying that teaching of mother tongue in Slomšek's School is still ongoing, for all generations. All active associations of the Slovenian Society of Victoria, which support the School financially, are satisfied with its educative work (Peter Mandelj, Chairperson of the Slovenian Welfare \& Information Office Inc., June, $3^{\text {rd }} 2010$ ). 
This period was also marked by the culmination of the thirty years of effort by the Slovenian immigrant community in organizing and initiating the necessary facilities and associated activities in pursuit of educational, cultural, religious roles of religious centres such as Sts. Cyril and Methodius in Kew, Melbourne, as well as in obtaining advantages for the community itself. Achievement of the set goals and efforts is incorporated in the implementation of the centre's role as the core of Slovenian population in Victoria, which is the case today.

\section{"Thoughts" is infallible in religious, social and cultural life of Australian Slovenes}

Thoughts (Misli), initially dedicated to the members of "Slovenec", the first Slovene organisation in the New South Wels area, was first published in Sydney. It is a religious and cultural publication, written in the Slovenian language. Its first issue saw the light on January $25^{\text {th }} 1952$. It was edited by the Slovenian Franciscan Priests (Bernard Ambrožič in Sydney, Bazilij Valentin, Metod Ogorevc, Ciril Božič, Marija Anžič in Melbourne) as a monthly magazine, from its beginnings in 1952 until 1972 in Sydney and was then relocated to Melbourne from where it has been issued to date. The global goals of the magazine have always been ..." to help Slovenes living in Australia, empathy in the new living situation, habits and customs of the new country and growing homeland (Čuješ, J., Misli, 1961, April). The review soon became the "most read material" within the Slovene ethnic community, even though the authors of the majority of articles had no journalistic qualifications or public experience. The magazine makes still today the rare attempt in collecting the data of residence of the Slovenes, national mobility, birth, marriages and other important data of Slovenian Australians across the federal state.

\section{Conclusion}

Australian Slovenes living in Victoria State are rather dispersed. The particular active role in ensuring communication between them is played by the "Slovenian Religious Centre Sts. Cyril and Methodius" in Melbourne. The Centre undertook the role of a connector in several social fields of the life of the immigrants. With no doubt, the greatest success was in facilitating connections and not creating more barriers among Slovenes. An important role is also played by the worldwide web, through which the Centre informs stakeholders about its activities. It is also an important information centre for communication with the global Australian society.

The Centre has achieved targets greater than those originally anticipated by the Franciscan mission, which has always been actively involved in the life of Slovenian immigrants in Victoria and beyond, in the cultural, social and educative fields. The results of the centre are visible in the efforts in preserving the identity of the Slovenian immigrant communities in Australian society, which has not always been in favour of maintaining the process, let alone feeding the next generation with 
values, traditions and cultural particularities of their emigrant ancestors. However, the majority of the sources, when talking about the objectives of the Centre, emphasized the "players" of the Centre, some of which stand out, in particular Fathers Bazilij Valentin and Ciril Božič, with their staff far exceeded its mission.

Warmest thanks go to them all, not only for their motivational role, but (mostly) for promoting the preservation of Slovenian values, customs and traditions. Their presence in many areas of Australian Slovene lives have not allowed the Slovenian community to be drowned in the mainstream and global Australian society.

Last, but not least: today, the centre is a powerful factor in the lives of Australian Slovenes in Victoria and beyond. And, finally, in 1990 it was also the focus and central initiative and stimulus, together with other Slovene associations in Victoria, in helping and supporting the development of democratic processes and democracy in the homeland Slovenia. By providing regular information to their countrymen, in co-organization with Victoria's Committee, the National Council of Victoria under the umbrella of the Slovenian World Congress, Australian Slovenian Conference, gathering political support in the process of international recognition, co-organizing peaceful demonstrations in supporting the separation aspirations of Slovenia from Yugoslavia in front of the provincial Parliament in Melbourne, organising a meeting with Bob Hawke (President of the Australian Government) and others, the Centre made an invaluable contribution when the Australian Government, as the first non-European country, recognized the Republic of Slovenia on January $16^{\text {th }} 1992$, as an independent and sovereign state (Valentin, 1991 Valentin, 1992; Klemenčič, 2005, Božič, 2010).

Our study, in which we conducted more than 300 individual interviews with Australian Slovenes, in March and April 2010 however, has shown that the young generation of descendants, born in Australia, are becoming increasingly aware of the memory, behaviour, knowledge and the characteristics and peculiarities of the society from which their ancestors came. To this end, the role of the Slovenian Religious Centre Ss. Cyril and Methodius will always remain very contemporary.

\section{Bibliography}

Birsa, I.: Slovenians in Australia, Graduate School of Education, Melbourn, 1994.

Božič, C.: Misli, leto 54, št.5, maj 2005, Melbourne

Čebulj Sajko,B.: Med srečo in svobodo. Avstralski Slovenci o sebi, Ljubljana, 1992.

Gelt, D.; Ferfolja,V.: Pax et bonum - Mir in dobro, Slovenska verska in kulturna središča v Avstraliji; 2002, Melbourne

Klemenčič, M.: Delovanje slovenskih izseljencev v Avstraliji za neodvisno Slovenijo. V: Klemenčič,M.(ured): Viri o demokratizaciji in osamosvijitvi Slovenije, Del 4; 2005.

Koderman, M.: Slovenski izseljenci v Viktoriji. Fakulteta za humanistične študije, Koper, 2007. 
Koderman, M.: Osnovanje in delovanje Slovenskega verskega središča Sv. Bratov Cirila in Metoda v Melbournu v Avstraliji, Razprave in gradivo, 53-54, 340-366. Inštitut za narodnostna vprašanja, Ljubljana, 2007.

Okorn, K.: Obisk v Melbournu, Misli, April, No 4, leto1, 1952.

Valentin, B.: Misli, No. 5, maj, , leto 10, 1961.

Valentin, B.: Misli, No. 6, junij, leto 25, 1976.

Valentin, B.: Misli, No. 7, junij, leto 40, 1991.

Valentin, B.:Misli, No. 1-2, januar-februar, leto 41, 1992.

Individual guided Interviews with: 2010.).

Alfred Brežnik, Honorary Consul of the Republic of Slovenia, Sydney, March 17'th

Peter Mandelj, Chairperson of the Slovenian Welfare \& Information Office Inc., June, 3'rd 2010, Melbourne.

Fr. Valerijan Jenko, $12^{\text {th }}$ March 2010, Sydney, New South Wels.

Silva Bogovič, $19^{\text {th }} 3.2010$, Melbourne, Victoria,.

Ivan Lapuh, $22^{\text {th }}$ March, 2010, Melbourne, author's personal archives.

Lucija Srnec, $25^{\text {th }}$ March 2010, Melbourne, author's personal archives. archives.

Fr. Ciril Božič, during March-April, 2010, staying in Kew; Melbourne, author's personal archives.

Marija Anžič, during March-April, 2010, staying in Kew; Melbourne, author's personal

Metodički obzori 7(2012)2

Izvorni znanstveni rad

UDK: $37(945=163.6)$

Primljeno: 27. 1. 2011.

\title{
SODOBNI IZOBRAŽEVALNI PROCESI V SLOVENSKEM VERSKEM SREDIŠČU SV.BRATOV CIRILA IN METODA V AVSTRALIJI V OHRANJANJU IDENTITETE SLOVENSKIH IZSELJENCEV
}

\author{
Prof. dr. sc. Jana Goriup \\ Faculty of Arts, \\ University of Maribor (Slovenia) \\ e-mail: jana.goriup@uni-mb.si
}

Pov z e te $k$

Izseljevanje Slovencev v Avstralijo, še posebej v državo Victoria, se je intenziviralo po II.svetovni vojni in doseglo svoj višek v 70.letih prejšnjega stoletja. Glede na dejstvo, da so Slovenci v Avstraliji četrta najštevilčnejša neevropska priseljenska skupnost, so le-ti že zgodaj začutili potrebo po organiziranosti tako na kulturni kot socialni ravni. Prispevek obravnava 
izobraževalno vlogo eno izmed ključnih in prvih organizacij slovenskih izseljencev: Versko središče Sv.bratov Cirila in Metoda v Kew, v Melbournu, ki je bilo (in še vedno je) desetletja zavetišče mnogim slovenskim družinam, s posebnim ozirom na izobraževalni vlogi frančiškanskih duhovnikov. Ko so le-ti takoj po svojem prihodu leta 1955 pričeli graditi široko mrežo svojih izobraževalnih in vzgojnih aktivnosti, je Središče preseglo meje svojega osnovnega poslanstva Katoliško- frančiškanskega misijona. Ob globalnem cilju uresničevanja njihove osnovne verske, družbene in izobraževalne vloge pa (je) Središče uresničuje(-valo) tudi ohranjanje slovenske dediščine $\mathrm{z}$ izobraževanjem za inkluzijo slovenskih priseljencev v vsakodnevno avstralsko življenje. Skozi zastavljene aktivnosti Središča je Slovenska skupnost uspela oblikovati imanenten in specifičen način transmisije narodnih in državljanskih značilnosti in posebnosti svojega avtohtonega okolja, tako svojim mladim potomcem kot tudi širšemu avstralskemu družbenemu okolju (z mesečnikom "Misli", slovensko šolo, jezikovnimi razredi in jezikovnimi tečaji, pevskimi zbori, športnimi aktivnostmi, slovenskim radiom idr.).

In, ne nazadnje, prispevek je rezultat avtoričinega aktivnega raziskovanja $\mathrm{z}$ neposredno udeležbo v raziskovanju izobraževalne vloge Slovenskega verskega središča v Kew, v širšem sklopu raziskovalnega programa "Vloga frančiškanskih duhovnikov v Avstraliji v ohranjanju slovenske identitete Slovencev v avstralski družbi”. Cilj avtoričinega raziskovanja je bil ugotoviti, ali so navedene izobraževalne in vzgojne aktivnosti prispevale $\mathrm{k}$ vzpostavitvi in utrjevanju pozitivnih odnosov med večinsko (avstralsko) in manjšinsko (slovensko) etnično skupnostjo (Avstralskih Slovencev).

Ključne besede: management identitete, izselitev, državljanstvo, Slovenska izseljenska skupnost, frančiskanski duhovnik. 